\title{
A Comparison of World and Domestic Price Volatilities of Oilseeds: The Ethiopian Case
}

\author{
Zerihun G. Kelbore \\ University of South Africa, South Africa \\ zehagu@gmail.com
}

\begin{abstract}
This study investigates and compares oilseeds price volatilities in the world market and the Ethiopian market. It uses a monthly time series data on oilseeds from February 1999 to December 2012; and analyses price volatilities using unconditional method (standard deviation) and conditional method (GARCH). The results indicate that oilseeds prices are more volatile, but not persistent, in the domestic market than the world market. The magnitude of the influence of the news about past volatility (innovations) is higher in the domestic market for Rapeseed and in the World market for Linseed. However, in both markets there is a problem of volatility clustering. The study also identified that due to the financial crisis the world market price volatilities surpassed and/or paralleled the higher domestic oilseeds price volatilities. The higher domestic oilseeds price volatility may imply that the price risks are high in the domestic oilseeds market. As extreme price volatility influences farmers ' production decision, they may opt to other less risky, low-value and less profitable crop varieties. The implications of such retreat is that it may keep the farmers in the traditional farming and impede their transformation to the high value crops, and results in lower income hindering the poverty reduction efforts of the government. This is more important to consider today than was before, because measures undertaken to reduce poverty must bring sustainable change in the lives of the rural poor. For this reason, agricultural policies that enable farmers cope with price risks and enhance their productivity are crucial.
\end{abstract}

Keywords: Oilseeds; Price Volatility; GARCH; World; Ethiopia

\section{Introduction}

Prices of agricultural commodities undergoing rapid adjustments were in the spotlight following the food crises in late 2007 and 2008, and again more recently in the summer and fall of 2010, raising concerns about increased price volatility, whether temporal or structural. The problems face all countries, which produce agricultural commodities, but are more serious for agricultural commodity dependent countries, which are dependent on agricultural commodity export. However, it is important to distinguish between the ex ante effects of volatility and ex post effects of extreme outcomes. The ex ante effect of volatility is that it induces farmers decisions towards or away from risky activities, whereas the ex post effect results from farmers adjustment of their expectations of future incomes in response to current earnings, or their current expenditure plans to the income short falls that they find difficult to cope with (Dehn et al., 2005). The same study shows that although poorer farmers consider weather-related risks, yield risks, illnesses of household members and weak demand for their off-farm labor as the main sources of their risks, price risks appear more important for commercially oriented farmers with surplus production and cash crop incomes. Evidences from coffee exporting developing countries, Nicaragua and Dominican Republic, show that price risks are the main sources of income risk (Ibd.).

Thus, in primary agricultural product exporting countries, uncertainty may have an impact on crop choice. To deal with the uncertainty and the resulting risk, farmers may engage in diversifying their farming across crops or family labor inputs across agricultural and non-agricultural activities. This may prevent farmers from exploiting comparative advantages, yet it can be effective in reducing risk. It may also negatively influence the likelihood of adopting better agricultural technologies and improving farming efficiency. As a result, it retards economic growth and puts substantial strain on efforts to reduce poverty. The impact of price volatility is high on governments that heavily depend on revenues from commodity exports. The linkage between commodity prices and government revenues can be either direct, through export taxation, or indirect, if fluctuations in commodity export revenues are transmitted to the broader economy and thence to government receipts (Dehn et al., 2005). However, the impact of variability of commodity export revenues on government revenues will be broadly proportional to the share of the commodity exports in the overall exports. Since African countries have been less successful in diversifying their primary commodities export profile, the impacts of export revenue variability on government revenues are higher in the African coffee producing countries than Latin American countries (Gilbert 2003 cited in Dehn et al., 2005). Further the study indicates that in some African countries like 
Kenya, Tanzania, and Cameroon diversification of sources of revenues has reduced the impacts of export revenue variability on government revenue. However, in most cases governments remained reliant on taxes of the traditional commodity exports. The implication of this is that commodity exporting African countries mainly need to have policies that encourage diversifying their sources of revenue so that the pressure from the export volatility of commodities on the macroeconomic stability could be reduced. From the above discussion, we learn that commodity price volatility has formidable implications at the household level through its effects on production and consumption decisions, and on the macro level through its impacts on government revenue.

With this understanding, in this study we investigate price volatilities of domestic oilseeds prices and world oilseeds prices, and compare the degree of volatility in both markets. Investigating the price volatility of domestic oilseeds is important for three reasons. First, as oilseeds are the second largest export items in the Ethiopian primary commodity export profile, the implications of price volatilities in the prices of these commodities would be formidable both on the welfare of producer households that cultivate oilseeds for commercial purpose. Second, we characterize the oilseeds price volatility patterns both in the domestic market and in the world market and compare the magnitude of the volatility between the two markets. Third, and most importantly, understanding the domestic price volatility may help to identify cause of the shock and design appropriate policies that help in overcoming the adverse effects of extreme volatility on household 's production decisions, and hence on government revenue. This is because higher price volatilities may imply price risk and influence production decisions of oilseeds producing households. This, in turn, may affect level of oilseeds production and hence export levels, with an implication on government revenue. In Ethiopia Oilseeds are the second largest export items and support nearly 4 million small holder farmers, account for $7 \%$ of total area under grain crops, and 3\% of the total grain production. Unlike any other grain crops in the country, around $50 \%$ of the oilseeds produced are marketed while $35 \%$ used or household consumption and $13 \%$ kept as a seed for the next season (CSA, 2012). Thus, the oilseeds sub-sector due to its commercial orientation could be a vital starting point in the commercialization of the agricultural sector, and hence transformation of the agricultural sector to high value crops.

The oilseeds have been in the export items list of Ethiopia for a long time. When compared with cereals, which have no significant contribution in foreign exchange earnings, the oilseeds are important contributors to the country's foreign exchange earnings and help in diversifying the primary commodity export profile and relieve the heavy dependence on coffee as the crucial source of foreign exchange earnings. Recently, for instance, the exports of sesame have overtaken the long held position of coffee as the major foreign exchange earning export item. This shows that there is a potential in the oilseeds subsector that enable the country diversify its primary commodity export profile towards high value crops such as oilseeds, pulses, vegetables, and fruits. The recent addition of flower export and its growing importance as a source of foreign exchange is also an indication that rather than relying on a few primary commodities diversifying on the export profile helps in dealing with shocks in primary commodity prices. Despite the importance of the sub-sector, the attention given to the oilseeds sector has been minimal. Studies conducted to characterize the local oilseeds market are very few and basically focus on value chain analysis. For instance, in an effort to show the importance of other primary commodities that have the potential to contribute to the diversification, Rashid et al. (2010) shows the potential of pulses in the Ethiopian agriculture, challenges in the pulses value chain, and implies the way forward. The study shows that pulses account for $10 \%$ of the agricultural value addition, and are the third largest export crops following coffee and sesame. Most importantly, pulses, as a high value export crop, contribute greatly towards the small holder farmers' income, serve as a relatively cheaper sources of protein that account approximately $15 \%$ of protein intake by farm households. However, the potential of the pulses sector is constrained by low productivity, currently blow $50 \%$ of the potential; undeveloped export markets due mainly to inconsistent policy interventions, lack of scale efficiencies as small holders dominate in the production, and poor market acumen (Rashid et al., 2010).

Table 1: Shares of Coffee, Oilseeds, and Pulses out of the total export value (\%)

\begin{tabular}{|c|c|c|c|c|c|c|}
\hline Export crop item & $\begin{array}{l}\text { Year } \\
2006 / 07\end{array}$ & $2007 / 08$ & $2008 / 09$ & $2009 / 10$ & 2010/11 & $2011 / 12$ \\
\hline Coffee & 35.80 & 35.80 & 26.00 & 26.40 & 30.60 & 26.40 \\
\hline Oilseeds & 15.80 & 14.90 & 24.60 & 17.90 & 11.90 & 15.00 \\
\hline Pulses & 5.90 & 9.80 & 6.30 & 6.50 & 5.00 & 5.10 \\
\hline
\end{tabular}

Source: NBE Annual Reports various Years 
As Table 1 shows the share of the oilseeds out of the total value of exports declined between 2006/07 and 2011/12. The share of oilseeds out of the total export value reached the maximum in 2007/08 over the six years period between 2006/07 and 2011/12, and then dropped subsequently. The fluctuations in export earnings from these commodities are commensurate with the fact that primary commodities are vulnerable to shocks in the world market. Such vulnerability to external shocks, which is beyond the control of the exporting countries, substantially hampers the livelihoods of poor smallholder farmers and results in uncertainties in production decisions and affects government revenue. Thus, studies that put the tradable sector into international perspectives and analyze its linkage to the world market are essential to forecast the movements of the world market trend and its linkage to domestic market and hence the implications on farm households. This study, focusing on Ethiopia, analyzes and compares the domestic oilseeds price volatility to that of the world market counterpart. It also explores the production, consumption, and trade performance of oilseeds both in the world market and in the domestic market. Using a historical data from February 1999 to December 2012, we have analyzed the unconditional and conditional price volatilities of oilseeds. The unconditional volatility is studied using standard deviation of monthly price changes (log of price returns), and the conditional volatility analyzed using GARCH $(1,1)$.

The results reveal that the unconditional price volatility comparison over different periods between 1999 and 2012 shows that over the entire period the unconditional price volatilities of oilseeds are higher in the domestic market than the World market. However, when observed periodically, the unconditional price volatility tends to follow the World market situation. The conditional variance estimates (GARCH $(1,1)$ ), on the other hand, imply that in the domestic market there is no problem of volatility persistence whereas volatility persistence appears the characteristic of the World market. Volatility clustering happens to be the common feature of both the domestic and the world market. Nonetheless, the magnitude of the influence of the news about past volatility on current volatility differs across crops and markets. The magnitude of the influence of the news about past volatility (innovations) is higher in domestic markets than the World market for Rapeseed, whereas in the case of Linseed the effects of the news are higher on the world market than the domestic market. The remaining parts of the paper are organized as follows section 2 describes production, consumption, and trade of oilseeds in the world and in Ethiopia, section 3 discusses data source and methodology; section 4 provides results and discussion; and section 5 concludes.

\section{Overview of the World and Domestic Oilseeds Sector}

In this section we briefly touch up on the performance of the oilseeds sector at the national and world levels. To this end, we discuss production and trade performances and briefly highlight growth in consumption of oilseeds in the world and due to lack of time series data on domestic consumption of oilseeds we cannot highlight the growth and pattern of domestic consumption of oilseeds. World, production of oilseeds has shown an overall growth rate of 83 \% between the years 1995 and 2012. However, the annual growth rate of production has been highly volatile with a coefficient of variation of $131 \%$ due to various reasons, which may include weather variability, change in cropping pattern, and price volatility, among others. As can be seen from Figure 1, the growth rate in area cultivated for oilseeds production has shown an overall growth rate of $38 \%$ between the years 1995 and 2012. The yield per hectare has shown an increase of 33 percent (increased from 1.53 in 1995 to 2.04 tonnes per hectare in 2012) implying that at the global level a great deal of improvement in productivity in the oilseeds production has come from the use of improved technology applied in the farming of oilseeds. Consolidating this argument, the correlation between the growth rates of area cultivated and yield levels appears to be -0.35 implying that an increase in area cultivated does not necessarily result in an increase in output of oilseeds (see Figure 2).

Although area harvested and yield have shown a similar average growth rate over the entire period between 1995 and 2012, they have shown a substantial difference in the fluctuation of the annual growth rates provided by their coefficient of variation of the growth rates, $160 \%$ for area cultivated and $269 \%$ for yield. In line with the above argument, the higher level of variability in yield can be associated with the increased application of improved technology in the production process of oilseeds. Figure 2 below shows that the movement in the growth rates of area cultivated and yield indicates the inverse relationships between them. We observe that an increase in the growth of area cultivated is not accompanied by a corresponding increase in yield level and an increase in yield level is not entirely a result of an increase in area cultivated. Thus we may conclude that production of oilseeds at the global level has shown a 
remarkable growth over the period under consideration largely owing to improvements in oilseeds farming technology.

Figure 1: Global Oilseeds Production Annual Growth Rate (1996-2012)

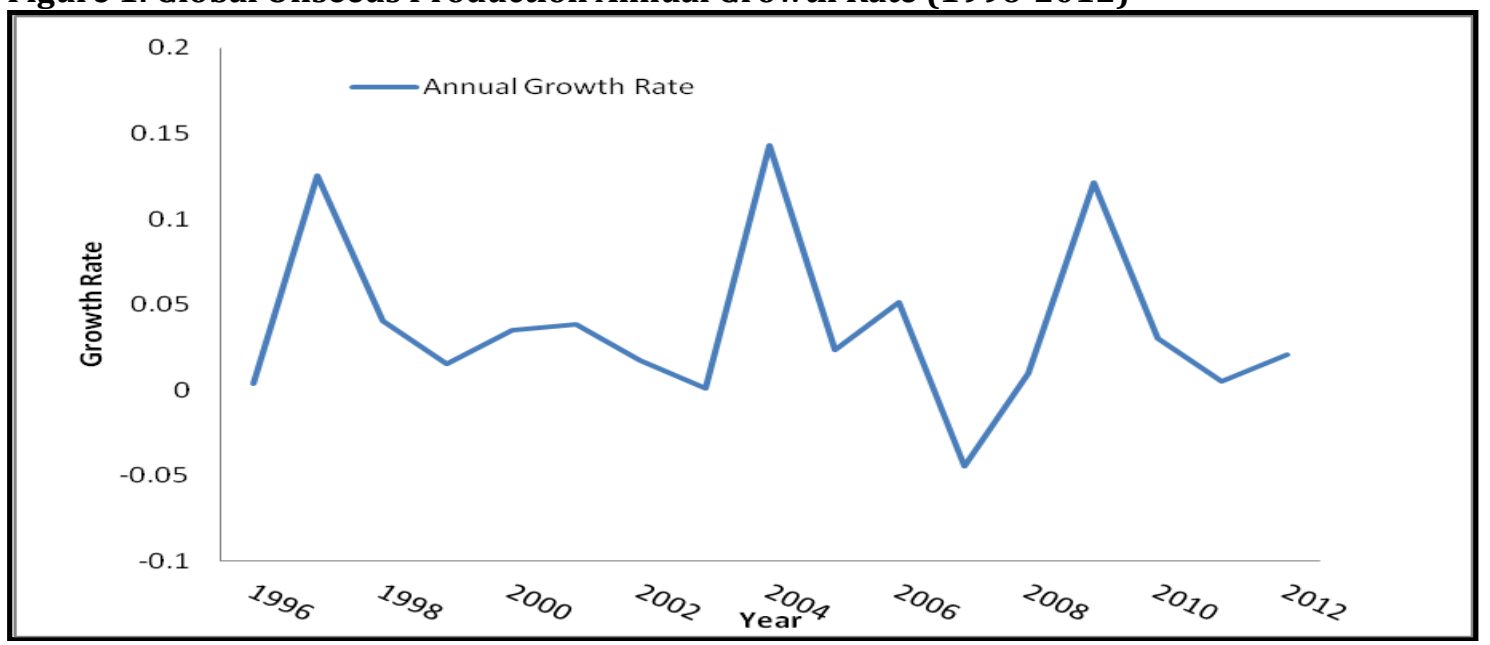

Source: FAOSTAT, 2012

Figure 2: Growth rates of area harvested and yield, Global

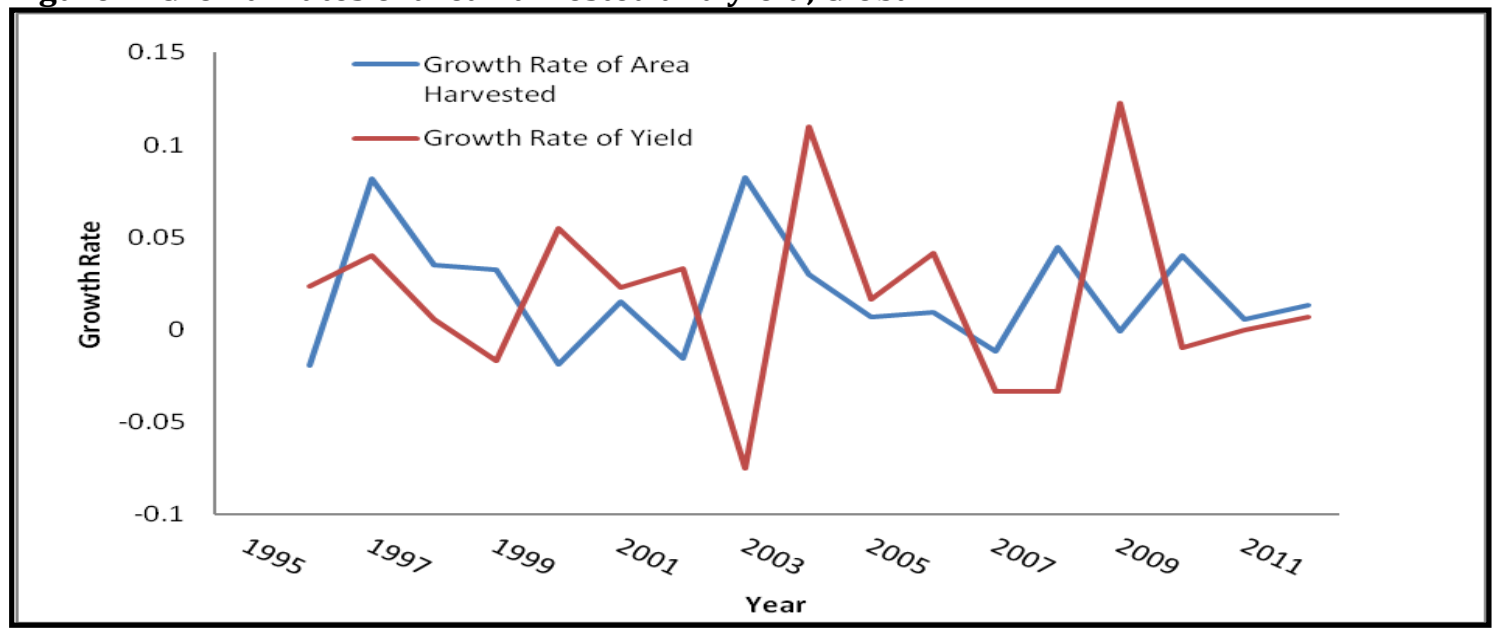

Source: FAOSTAT, 2012

In Ethiopia oilseeds constitute $7 \%$ of the total area (818.5 thousand ha) under grain crops (cereals, oilseeds, and pulses) and 3\% of the total grain production. The sector supports around 4 million small farmers that produce oilseeds for domestic consumption and the market. The major oilseeds cultivated are Nigger seed (nueg), linseed, groundnuts, sunflower, sesame, and rapeseed. Of these, Nigger seed accounts for $37 \%$ of the total area under oilseeds and $29 \%$ of total oilseeds production. Sesame is the second largest oilseed following Nigger seed, it accounts for $29 \%$ of total area under oilseed crops and $25 \%$ of total oilseeds production. Linseed, Groundnuts, and Rapeseed are also the other important oilseeds produced in the country. Linseed, Groundnuts, and Rapeseed cover $16 \%, 11 \%$, and $6 \%$ of the total area under oilseed crops and $17 \%, 17 \%$ and $10 \%$ of the total oilseed production, respectively. Oilseeds production over the period 1974 to 2012 shows that between 1974 and 1993 production of oilseeds has shown a remarkable growth that mainly came from the gains in productivity (see appendix A). However, the change in production between 1994 and 2012 has not been as remarkable as it had been prior to 1993 and the registered growth resulted from area expansion. This is striking for two reasons. First, prior to 1993 the policy environment towards agriculture and the broad economy was not considered favourable to bring growth to the agricultural sector and the overall economy. It has also been implied by various studies that the incentives to stimulate productivity in the agricultural sector have been non-existent. Rather, the output market had been centralized and price controls were put in place depressing the price levels far below the market prices (Rashid et al., 2009). Befekadu \& Tesfaye (1990), on the other hand, show that the increased productivity of oilseeds during the Socialist regime may relate 
to the shift in the mix of production as farmers switch from production of cereals to oilseeds in order to evade the grain delivery quota set by the Agricultural Marketing Corporation. ${ }^{1}$

Second, after 1993 the new economic policy reforms introduced appeared to be favourable in terms of getting-rid-off the distortions that dragged the economy backwards and tied up the economic agents from fully exploiting the opportunities, that possibly come along their way. With the hope of reigniting the agricultural sector the Transitional Government in 1991 adopted a strategy known as Agriculture-Led Industrialization (ADLI). Since then ADLI lived up as a flagship strategy of the agricultural sector. In the face of such a strategy and other subsequent agricultural policy reforms and restructuring of the input and output markets, and improving infrastructure over the last two decades, the performance of the second largest export commodity, oilseeds sector has been dismal. This is evidenced by the fall in the average growth rate of yield/ha from 14\% between 1974 and 1993 to 5.4\% between 1994 and 2012 . However, the average yield/ha in absolute terms increased from 4.7 (1974-1993) to 5.8 metric tonnes (1994 and 2012).

\section{Figure 3: Production of Oilseeds (1995-2012)}

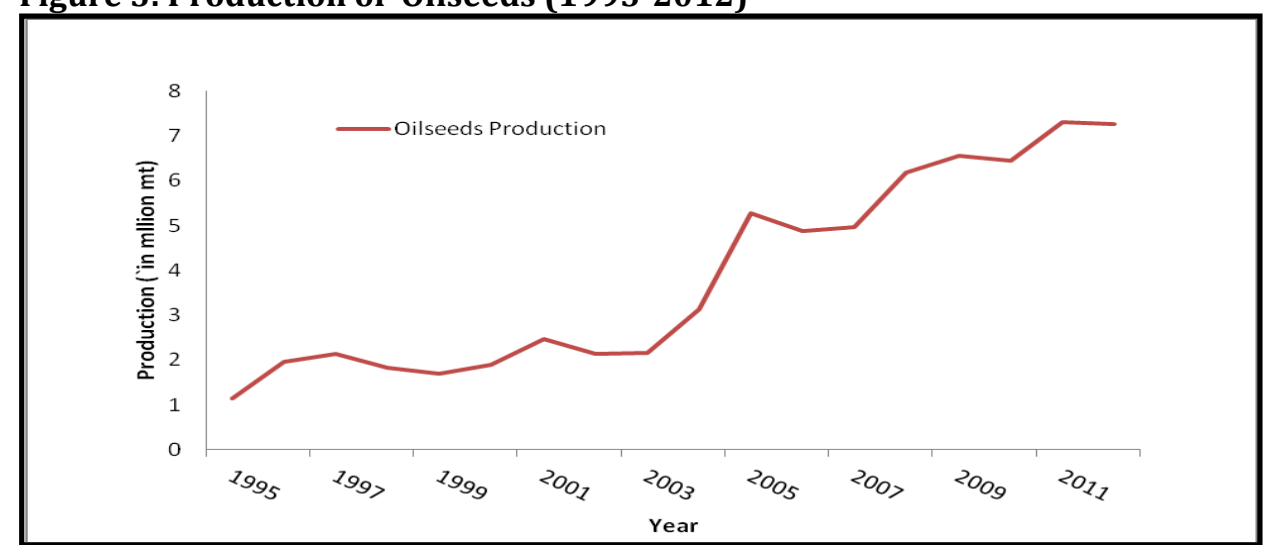

Source: CSA Agricultural Sample Survey Reports various years

Figure 5: Export and Import Quantities of World Oilseeds from 1961 to 2010

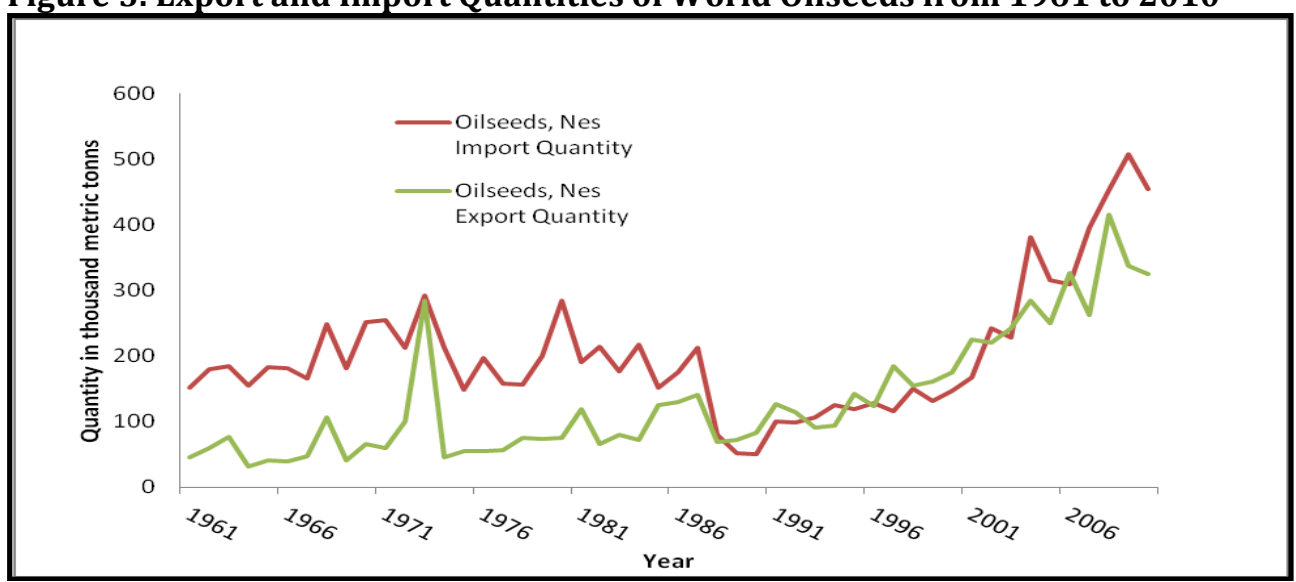

Source: FAOSTAT, 2012

\footnotetext{
${ }^{1}$ AMC was established in 1976, with the support from the World Bank. The corporation was tasked with a range of activities, which include handling almost all agricultural input and output markets. It determines annual quotas that farmers and traders had to supply to the corporation at a fixed price, which is far below market prices in most areas. It had put restrictions on private grain trade and interregional grain trade. As a result of these restrictions, cereal production depressed over the years the restrictions were in place and farmers reportedly evaded such restrictions by resorting to the production of oilseeds on which the restrictions were not imposed (Lirenso, 1995)(italics added by the author).
} 
The world export trends of oilseeds since 1961 to 2010 are demonstrated in Figure 4. The Oilseeds export pattern shows a growing trend since 1961. However, it had peaked between the years 1970 and 1973 and dropped back to its pre 1970 level. After the year 1974, the oilseeds export increased persistently. The dramatic rise in exports took place since the year 1994 onwards. At the national level, the oilseeds trade performance implies that export had reached 10 thousand metric tonnes in early 1970s and dropped in late 1970s and remained below 50 thousand metric tonnes during the entire period of the Socialist regime (see Figure 6). However, the trend started to pick up only after the demise of the Socialist regime and the enactment of a new economic path in 1991. The dramatic rise in exports since then was briefly thwarted between 2006 and 2008; probably owing to the fall in demand following the financial crisis occurred during the same period. Though Ethiopia is not a significant importer of oilseeds, the amount of oilseeds imported, which remained below 5 thousand metric tonnes until 2005 and peaked to 24 thousand metric tonnes in 2006, has plummeted during the period of the world financial crisis. Thus, the fall in exports and imports during the financial crisis may imply that the fall in exports may have been compensated by the fall in imports and hence what would have been exported may have served the domestic market.

Figure 6: Oilseeds export and import, domestic market

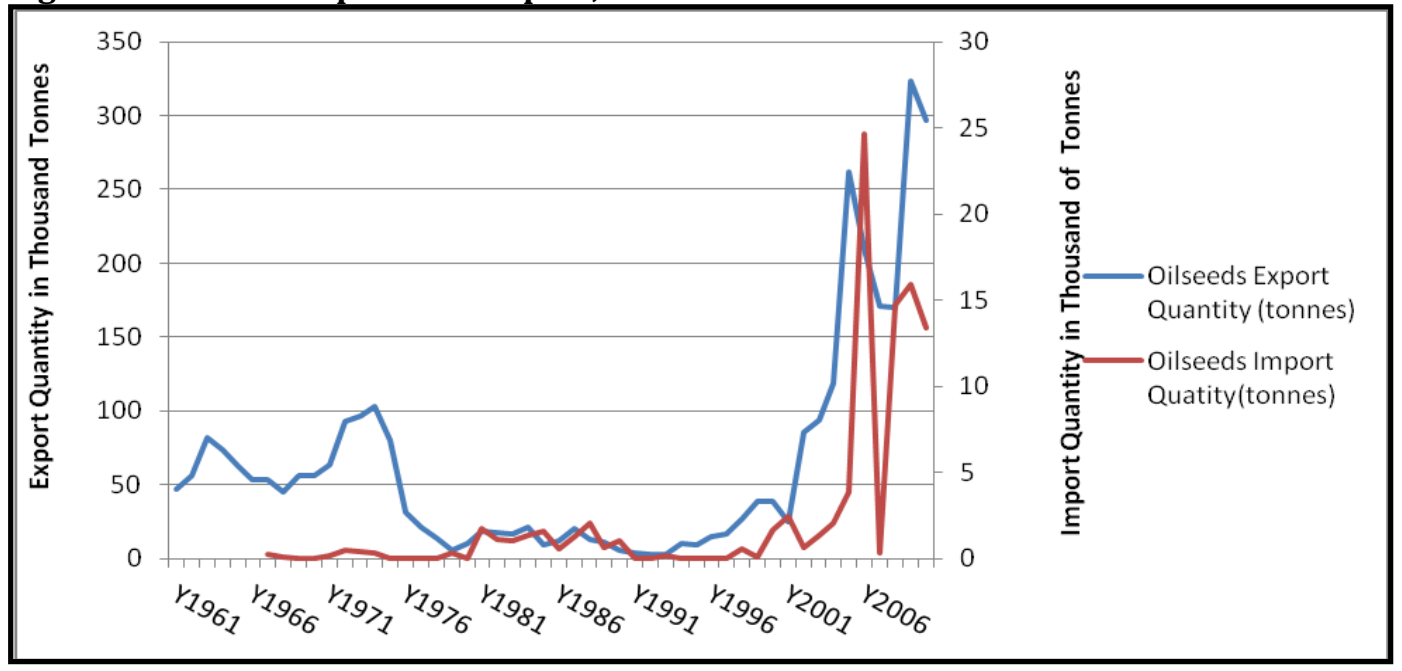

Source: FAOSTAT, 2012

Figure 7: Growth Rate of Consumption and Other Uses of Oilseeds

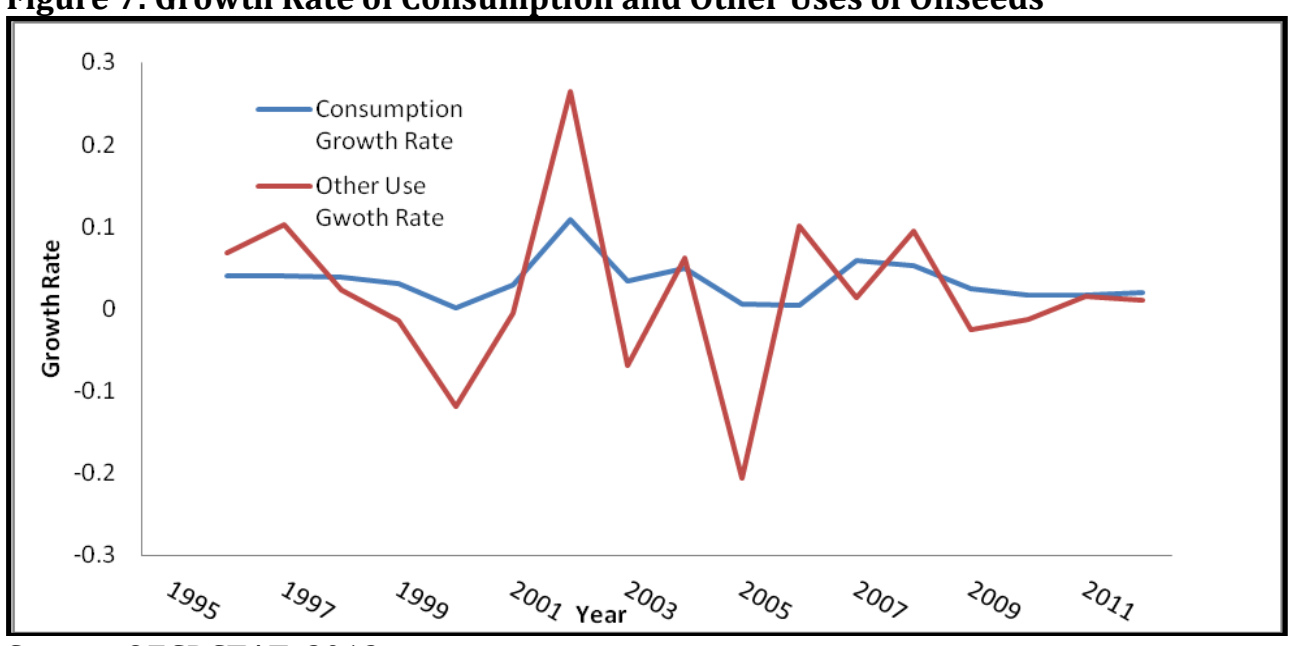

Source: OECDSTAT, 2013

The world consumption of oilseeds has increased between 1995 and 2012 and registered an average annual growth rate of 3.4\%; the growth in other uses of oilseeds averaged $1.8 \%$. However, the rate at which the consumption increases has slowed down since 2008 registering a growth rate below its 1999 level. However, the growth in other uses is much more volatile than the growth in consumption with $10.2 \%$ and $2.6 \%$ standard deviation, respectively (OECDSTAT, 2013). In Ethiopia, the data indicate that 
unlike cereals and pulses, oilseeds production is mainly for sale. CSA (2012) shows that $35 \%, 13 \%$ and nearly $50 \%$ of the oilseeds produced were used for household consumption, seed, and sale, respectively 2 .

\section{Data Source and the Empirical Model}

Data: For the analysis of price volatilities, we use a time series data on prices of Oilseeds for both domestic and international markets over the period between February 1999 and December 2012. The data for the domestic market is obtained from the Ethiopian Grain Trade Enterprise (EGTE). The international prices of the oilseeds are obtained from International Financial Statistics (IFS) database of the International Monetary Fund (IMF). The descriptive statistics of the domestic and world oilseeds prices are provided in Table 2\&3, respectively. As we observe from Table 2, between February 1999 and December 2012 Niger seed (nueg) appeared to have the highest average price, USD 51 per quintal. The variance over the entire period also witnesses that Niger seed has the highest variability, followed by Linseed.

Table 2: Descriptive Statistics of Domestic Nominal Oilseeds, February 1999 to December 2012

\begin{tabular}{llll}
\hline Statistics & Linseed & Niger Seed & Rapeseed \\
\hline Mean & 45.99 & 50.94 & 36.26 \\
Standard Err. & 1.40 & 1.60 & 1.26 \\
Standard Dev. & 18.10 & 20.62 & 16.23 \\
Minimum & 17.43 & 20.18 & 13.35 \\
Maximum & 101.03 & 109.49 & 88.15 \\
$\mathrm{~N}$ & 167 & 167 & 167 \\
\hline
\end{tabular}

Source: Author`s Computation using data obtained from EGTE

As Table 3 shows, between January 1999 and December 2012, Linseed oil registered a higher average price USD $894 / \mathrm{mt}$ followed by palm oil and soybean oil. In terms of variability, Linseed happens to be the most variable followed by Soybean. The price spikes provided by the range of the data series indicate that Soybean oil prices witnessed the largest price spike followed by Linseed Oil prices.

Table 3: Descriptive Statistics of International Nominal Oilseeds Prices, January 1999-December 2012

\begin{tabular}{lllll}
\hline Statistics & Linseed oil & Palm oil & Soybean oil & Rapeseed \\
\hline Mean & 894.01 & 568.97 & 689.43 & 366.54 \\
Standard Error & 30.92 & 22.11 & 24.37 & 12.40 \\
Standard Dev. & 400.82 & 286.59 & 315.81 & 160.77 \\
Minimum & 350.00 & 185.07 & 321.40 & 173.73 \\
Maximum & 1948.00 & 1248.55 & 1414.40 & 735.39 \\
$\mathrm{~N}$ & 168 & 168 & 168 & 168 \\
\hline
\end{tabular}

Source: Author`s Computation using data from IFS February 2013

Thus the descriptive statistics indicates that the difference in oilseeds prices volatile between the world and the domestic market depends on the types of oilseeds one wants to compare. The above evidence shows that Linseed price is more volatile in the world market whereas Rapeseed prices are more volatile in the domestic market. In the following section, we investigate these differences in volatility with the help of an empirical model.

\footnotetext{
${ }^{2}$ Followers of the Ethiopia Orthodox Church, which constitute more than $40 \%$ of the country`s population do not consume meat, dairy and dairy products during the fasting days which happen to be above 250 days when strictly executed. As a result, vegetable oils are widely used and hence oilseeds cultivation is an important agricultural activity with a huge potential domestic market.
} 
The Empirical Model: Following Balcombe (2010), we measure the level of price volatility over different periods classified based on reasons interesting for volatility comparison. That is, we compare volatility between periods 1999-2004, 2005-2008, and 2009-2012 and the entire period. The temporal classification of the data into the above-mentioned periods is important in two ways. First, it allows as comparing price movements before the onset of the global commodity price crises, to the crisis period, and to price developments following the crisis. As Figures 7 and 8 indicate that domestic oilseeds prices started to increase as of early 2005, peaked between 2007 and late 2008 and started to drop in early 2009 and again rose up in late 2010, and finally started to drop after late 2011. The world oilseeds prices, except Linseed oil, show a similar trend to that of the domestic price movements. Thus, we classified the period into three periods based on such development, and with the purpose of comparing price volatilities during the high commodity price period with price volatilities before the onset of the crisis and after the end of the major crisis. The classification into such temporal space helps in characterizing price volatilities during such different episodes characterized by different market developments. Second, linked to the first reason, classifying the comparison of volatilities into such time spaces helps us to identify how the world and domestic oilseeds markets have been behaving before, during, and after the commodity crisis.

Figure 8: Domestic Oilseed Prices February 1999 to December 2012. Source: EGTE

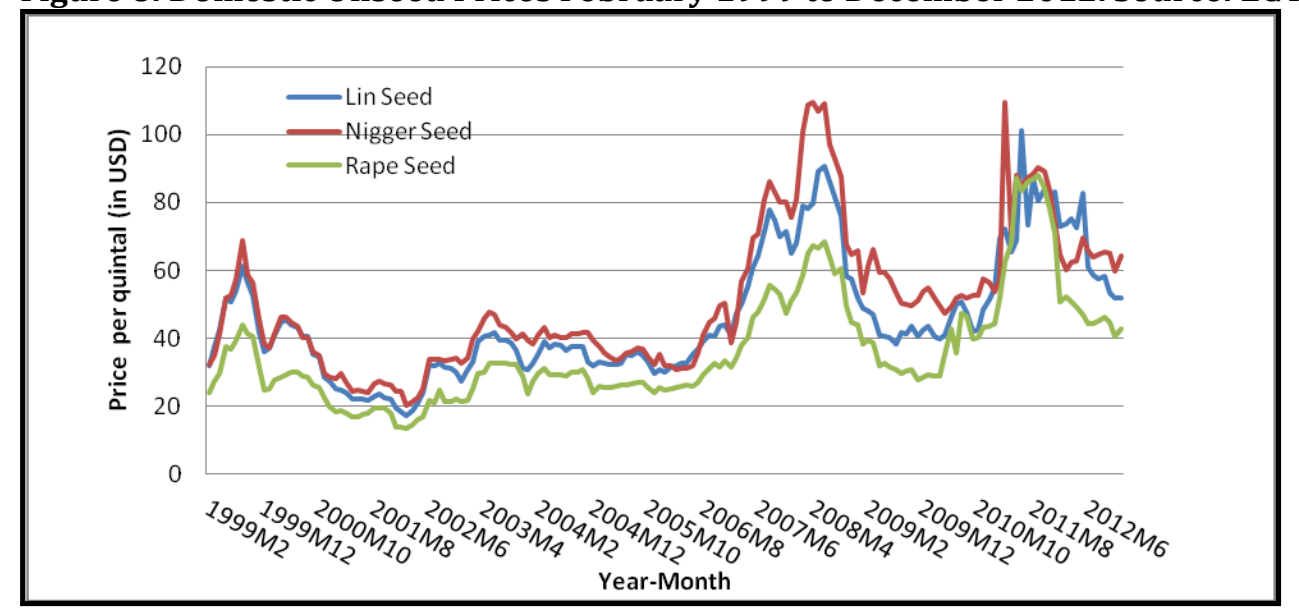

Figure 9: Domestic Oilseed Prices February 1999 to December 2012. Source: EGTE

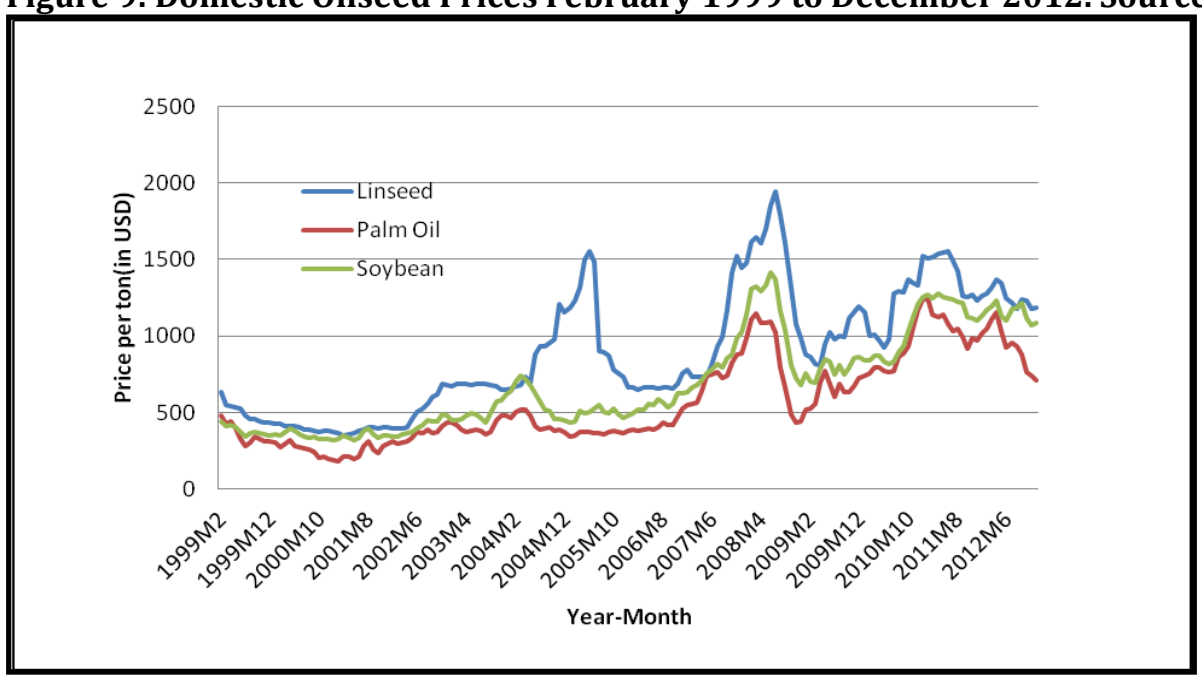

To measure the unconditional volatility we use the following simple specification:

$V=\sqrt{\sum \frac{1}{N-1}\left(p_{t}-\bar{p}\right)^{2}}$

Where $V$ volatility (standard deviation) is, $p_{t}$ is the log of the price return, $\bar{p}$ the mean of the log price return, and $N$ is the number of observations. This measure of volatility, which is a standard deviation of 
log price returns, provides the level of volatility over a specified period, but it doesn`t measure how it evolves within that period.

Thus, to investigate the movement of volatility over time we need to use models that help in capturing the change in variance of a variable over time. This leads us to models that study the volatility of a time series such as the Autoregressive Conditional Heteroscedasticity (ARCH) type models as first introduced by Engle (1982) and later generalized by Bollerslev (1986) and known as Generalized Autoregressive Conditional Heteroscedasticity (GARCH). The study of volatility or variability of a time series has been motivated by problems in finance. The rationale for the ARCH and the later generalization of ARCH, GARCH modelling is that the underlying forecast variance of a price return may change over time and it is predicted in a better way by past forecast errors. The later generalization by Bollerslev (1986) included past (lagged) variance in the explanation of future variance which help in reducing the number of lagged terms used in the ARCH model. Of all the GARCH models, GARCH $(1,1)$ is the most popular and widely used GARCH specification. For this reason, we also found it plausible to estimate the GARCH $(1,1)$ model. The mean and variance equations of the model, respectively, are given as:

$p_{t}=\omega_{0}+\omega_{i} p_{t-i}+\varepsilon_{t}$
$\delta_{t}^{2}=\alpha_{0}+\alpha_{1} \varepsilon_{t-1}^{2}+\beta_{1} \delta_{t-1}^{2}$

with the constraints $\alpha_{0}>0, \alpha_{1} \geq 0$, and $\beta_{1} \geq 0 . \delta_{t}^{2}$, is conditional variance because it is one period ahead forecast variance based on the past information. $\alpha_{1}$, which is the coefficient of the lag of the squared residual from the mean equation $\left(\varepsilon_{t-1}^{2}\right)$, is the ARCH term. It gives us the news about the volatility from the last period. The volatility clustering is implied by the size and significance of $\alpha_{1}$ while $\beta_{1}$ is the GARCH term.

The sum of the ARCH and GARCH terms, $\left(\alpha_{1}+\beta_{1}\right)$, measures a persistence of volatility. If $\alpha_{1}+\beta_{1}=1$, any shock to volatility is said to be permanent. This also may imply that the unconditional variance is infinite or an Integrated GARCH (IGARCH) process as indicated by Engle and Bollerslev (1986). In IGARCH volatility persistence is permanent and past volatility appears to significantly predict future volatility. If $\alpha_{1}+\beta_{1}>1$, volatility is said to be explosive. That is, a shock to volatility in one period will lead to even greater volatility in the next period.

Estimation Method for GARCH: In order to estimate the GARCH model, we first need to examine the time series properties of the data. Accordingly, we conducted a unit root test on the price series of both domestic and world oilseeds prices and found out that all the return price series are stationary (see appendix B). Then we test for the ARCH effects using the ARCH-LM test to check for whether ARCH effects exist in the price series. The test for ARCH effects in the price return series is conducted using the Lagrange Multiplier test proposed by Engel (1982) and the procedure is described in the following section.

Lagrange Multiplier (LM) Test for ARCH Effects: We use the Lagrange Multiplier (LM) test to identify whether each of the time series has ARCH effects. Engel (1982) proposed the LM test for ARCH effects in a time series. Under the null hypothesis, it is assumed that the model is standard dynamic regression, which can be written as

$y_{t}=x_{t} \beta+\varepsilon_{t}$

Where $x_{t}$ is a set of weakly exogenous and lagged dependent variables and $\varepsilon_{t}$ is a Gaussian white noise process,

$\varepsilon_{t} \mid I_{t-1} \sim N\left(0, \delta^{2}\right)$

Where $I_{t-1}$ denotes the available information set. The alternative hypothesis is that the errors are ARCH $(q)$,

$\varepsilon_{t}^{2}=w+\sum_{i=1}^{q} \alpha_{i} \varepsilon_{t-i}^{2}$

The straightforward derivation of the LM test provided by Engel (1984) leads to the $\mathrm{N}^{*} R^{2}$ test statistic, where $\mathrm{N}$ is the sample size and $R^{2}$ is computed from the regression of $\varepsilon_{t}^{2}$ on a constant and $\varepsilon_{t-1}^{2}, \ldots \ldots, \varepsilon_{t-q}^{2}$. Under the null hypothesis that there is no ARCH, the test statistic is asymptotically 
distributed as $\chi^{2}$ distribution with $q$-degrees of freedom. The intuition behind this test is that if the data are homoscedastic, then the variance cannot be predicted and variations in $\varepsilon_{t}^{2}$ will be purely random. However, when ARCH effects exist, large values of $\varepsilon_{t}^{2}$ will be predicted by large values of the past squared residuals. As an alternative form of the LM test, we may use the asymptotically equivalent Portmanteau tests, such as the Ljung and Box (1978) statistics, for $\varepsilon_{t}^{2}$. The results of the ARCH effect test for the variables used in this study are presented in Table 4 . The results show that all the domestic oilseeds price and world oilseeds price series have ARCH effects. However, among the world oilseed prices, for Soybean and Rapeseed the ARCH effect is observed at the second lag.

Table 4: Lagrange Multiplier Test for ARCH Effects on domestic and world oilseed price returns

\begin{tabular}{llll}
\hline & $\chi^{2}$ & $\boldsymbol{d} \boldsymbol{f}$ & $\boldsymbol{p}>\chi^{2}$ \\
\hline Domestic Prices & & & \\
Linseed & 10.93 & 1 & 0.00 \\
Nigger Seed & 31.45 & 1 & 0.01 \\
Rape Seed & 3.45 & 1 & 0.00 \\
World Prices & & & \\
Linseed Oil & 66.31 & 1 & 0.00 \\
Palm Oil & 4.29 & 1 & 0.04 \\
Soybean Oil & 8.11 & 2 & 0.02 \\
Rape Seed & 4.72 & 2 & 0.09 \\
H0: no ARCH effects & H1: ARCH (p) disturbance &
\end{tabular}

Thus, since we found ARCH effects in the price series, the estimation of ARCH/GARCH model can be made in order to find out the conditional price volatility overtime.

\section{Results and Discussion}

Price volatility of oilseeds in the domestic market: The price volatility computed using the monthly price returns (in logs) is reported in Table 5 for oilseeds traded in the domestic market. We measure volatility using standard deviation of the changes in log of monthly price changes over different periods in order to show changes in volatility over time. We compare volatilities over the entire period, pre-crisis period (February 1999 to December 2004), during the recent food crisis (January 2005 to December 2008), and the post crisis period (January 2009 to December 2012). We see that volatility has decreased during the commodity price boom in the world market, except Niger seed; however, in the post crisis period volatility increased in all commodities. We can also see that oilseeds prices have become more volatile in the post crisis period implying that the uncertainty of price movements may have implications on production decisions. The comparison of volatility between periods prior to 2005 and after 2009 shows an increase in volatility in the later period. The analysis of the nominal price volatility by commodity over the corresponding times appears nearly identical to the above discussion.

In what follows, we explain the change in volatility over the period under consideration. Firstly, we explore volatility clustering and persistence. For this we use estimates from GARCH $(1,1)$ model and explain how past volatility affects future volatility and the volatility clustering. In the estimation of Niger seed prices, $\alpha+\beta$ exceeded 1 indicating that GARCH $(1,1)$ does not fit the data and we do not provide discussion of Niger seed conditional price volatility. The estimation results for the volatilities of domestic oilseeds prices imply that in general the oilseeds prices in Ethiopia are volatile. $\alpha$ that demonstrate the contributions of past innovations (news) regarding volatility appear to be statistically significant for both oilseeds at $5 \%$. These results show that there are problems of volatility clustering in the domestic oilseeds prices. On the other hand, $\beta$ that shows the one period ahead forecast of volatility based on previous period volatility is found statistically significant for Linseed. Further, we conducted Wald test to check for persistence of volatility. As indicated in Table 6, volatility persistence in the linseed and rapeseed prices is rejected as the Wald test rejects the null hypothesis at $1 \%$ and $5 \%$ significance level, respectively. The test for the joint significance of $\alpha \& \beta$ shows that in all cases the parameters are significantly different from zero with $1 \%$ significance level. 
Table 5: Volatility Measure Using Standard Deviation of Log of Monthly Price Changes

\begin{tabular}{lllll}
\hline & All Period & $\mathbf{1 9 9 9 - 2 0 0 4}$ & $\mathbf{2 0 0 5}-\mathbf{2 0 0 8}$ & $\mathbf{2 0 0 9 - 2 0 1 2}$ \\
\hline Lin Seed & 9.3 & 9.1 & 7.4 & 11.4 \\
Nigger Seed & 10.5 & 9.0 & 9.5 & 13.5 \\
Rape Seed & 9.4 & 9.9 & 6.4 & 11.0 \\
Lin Seed & 8.8 & 8.3 & 7.0 & 11.1 \\
Nigger Seed & 10.1 & 8.2 & 9.5 & 12.9 \\
Rape Seed & 8.7 & 9.2 & 6.2 & 10.0 \\
\hline
\end{tabular}

Table 6: GARCH $(1,1)$ Coefficient Estimates for Oilseeds in the Domestic Market

\begin{tabular}{lll} 
Coefficients & Lin Seed & Rape Seed \\
\hline$\omega$ & 0.0034 & 0.0036 \\
& $(0.0011)$ & $(0.0015)$ \\
$\alpha$ & 0.2582 & 0.2461 \\
& $(0.1137)$ & $(0.1201)$ \\
$\beta$ & 0.3290 & 0.2944 \\
& $(0.1297)$ & {$[0.2325)$} \\
$\alpha+\beta$ & 0.5872 & 0.5405 \\
Wald Test $\left(\chi^{2}\right)$ & 9.21 & 5.56 \\
& {$[0.0024]$} & {$[0.0184]$} \\
Log Likelihood & 172.5405 & 175.4346 \\
$H_{0:} \alpha=\beta=0$ & 18.71 & 12.29 \\
& {$[0.0001]$} & {$[0.0021]$} \\
\hline
\end{tabular}

Parenthesis (.) and [.] show standard errors and $p$-values, respectively.

Wald test null hypothesis is $\alpha+\beta=1$.

Price volatility of oilseeds in the world market: The Oilseeds volatility, as provided in Table 7, show that the volatility of Palm oil prices appear more volatile prior to 2005. Linseed oil, Soybean oil, and Rapeseed prices exhibited the highest volatility between 2005 and 2008. Over the entire period between 1999 and 2012, we observe that the price of Palm oil shows the highest volatility (8.5\%), followed by Linseed oil (7.7\%). Between 1999 and 2004, Palm oil price appears more volatile than any other oilseeds.

However, between 2005 and 2008 Linseed appeared to be more volatile than other oil crops with 10.8\% volatility, followed by Palm oil (8.6\%). After 2008, it seems that the volatility of all oil crops has dropped; for instance, the volatility of Linseed dropped by about $36 \%$ (see Table 7). Next, we discuss the GARCH (1, 1) estimates for the World oilseeds prices. The results presented in Table 4.8 show that Palm oil, Soybeans, and Linseed oil price volatilities are not persistent as the Wald test of the null hypothesis $\alpha+\beta=1$ is rejected at 10,10 , and 5 percent, respectively. However, Rapeseed price volatility appear persistent as the Wald test failed to reject the null hypothesis with $\chi^{2}=1.42, p$-value $=23 \%$. The volatility clustering as provided by the $\alpha$ coefficient shows that all the oilseeds in the world market demonstrate problem of volatility clustering. That is, the news about volatility in the previous period $(t-1)$ tends to influence current volatility $(t+1)$. The size of the influence of news regarding past volatility on current volatility is $27,21,3$, and $61 \%$ for Palm oil, Soybeans, Rapeseed, and Linseed oil, respectively, and statistically significant at $5,10,5$, and $1 \%$, respectively. The GARCH term indicated by $\beta$ is also statistically significant at 5, 5, 1, and 5 percent level of significance for Palm oil, Soybean, Rapeseed, and Linseed oil, respectively; implying that variance of the previous period has a formidable impact on the current variance level. 
Table 7: Oilseeds Volatility Using Standard Deviation of Log of Monthly Price Changes, World

\begin{tabular}{lllll}
\hline & All period & $\mathbf{1 9 9 9 - 2 0 0 4}$ & $\mathbf{2 0 0 5 - 2 0 0 8}$ & $\mathbf{2 0 0 9 - 2 0 1 2}$ \\
\hline Nominal & & 5.5 & 10.8 & \\
Linseed Oil & 7.7 & 8.9 & 8.6 & 6.9 \\
Palm Oil & 8.5 & 6.0 & 7.4 & 7.8 \\
Soybean Oil & 6.3 & 5.9 & 6.3 & 5.3 \\
Rapeseed & 5.9 & & & 5.6 \\
Real & & 5.3 & 10.1 & \\
Linseed Oil & 7.3 & 8.8 & 7.3 & 6.3 \\
Palm Oil & 8.1 & 5.9 & 6.3 & 5.1 \\
Soybean Oil & 5.8 & 5.8 & 5.2 & 5.3 \\
Rapeseed & 5.5 & & & \\
\hline
\end{tabular}

Table 8: GARCH $(1,1)$ Coefficient Estimates for Oilseeds in the World Market

\begin{tabular}{lllll} 
Coefficients & Palm Oil & Soybeans & Rapeseed & Linseed Oil \\
\hline$\omega$ & 0.0016 & 0.0010 & 0.0006 & 0.0030 \\
$\alpha$ & $(0.0009)$ & $(0.0006)$ & $(0.0005)$ & $(0.0005)$ \\
& 0.2676 & 0.2106 & 0.0311 & 0.6090 \\
$\beta$ & $(0.1160)$ & $(0.1083)$ & $(0.0152)$ & $(0.1853)$ \\
$\alpha+\beta$ & 0.5083 & 0.5312 & 0.7683 & -0.0666 \\
Wald Test $\left(\chi^{2}\right)$ & 2.9647 & $(0.2249)$ & $(0.1450)$ & $(0.0249)$ \\
& {$[0.1799)$} & 0.7418 & 0.7994 & 0.5425 \\
Log Likelihood & 185.5658 & 233.4877 & 241.8562 & 223.3676 \\
H0: $\alpha=\beta=0$ & 0.77 & {$[0.0710]$} & {$[0.2328]$} & {$[0.0436]$} \\
& {$[0.3795]$} & {$[0.2973]$} & {$[0.0000]$} & {$[0.0002]$} \\
\hline
\end{tabular}

Parenthesis (.), and [.] show standard errors and $p$-values, respectively. Wald test null hypothesis is $\alpha+\beta=1$

Comparison of world and domestic price volatility of Oilseeds: As Ethiopia has a few number of commodities exported in the oilseeds category, it s not possible to make a comparison of price volatilities of all the items that appear in the section of world market price volatility analysis. For this reason, we limit our comparison of volatilities only to those commodities where relative comparison is possible. Thus in this section, we provide the comparison of Linseed and Rapeseed price volatilities in the world and Ethiopian markets. To begin with, we compare the unconditional price volatility of the Linseed and Rapeseed as measured by the standard deviation of the log of monthly price changes. As provided in Table 9, the domestic nominal and real prices of Linseed and Rapeseed are found to be more volatile when examined over the entire period under consideration. 
Table 9: Comparison of domestic and world unconditional price volatilities, Linseed and Rapeseed

\begin{tabular}{lllll}
\hline Domestic & All Period & 1999-2004M12 & 2005-2008M12 & 2009-2012M12 \\
\hline Nominal & & & & \\
Lin Seed & 9.3 & 9.1 & 7.4 & 11.4 \\
Rape Seed & 9.4 & 9.9 & 6.4 & 11.0 \\
Real & & & 7.0 & 11.1 \\
Lin Seed & 8.8 & 8.3 & 6.2 & 10.0 \\
Rape Seed & 8.7 & 9. & $2005-2008 \mathrm{M} 12$ & $2009-2012 \mathrm{M} 12$ \\
World & All period & $1999-2004 \mathrm{M} 12$ & & \\
Nominal & & & 10.8 & 6.9 \\
Lin Seed Oil & 7.7 & 5.5 & 6.3 & 5.6 \\
Rapeseed & 5.9 & 5.9 & & 6.3 \\
Real & & & 10.1 & 5.3 \\
Lin Seed Oil & 7.3 & 5.3 & 5.2 & \\
Rapeseed & 5.5 & 5.8 & &
\end{tabular}

The difference in the unconditional volatilities of the two commodities between the two markets reveals that the domestic Linseed nominal price volatility has exceeded its world counterpart by 17 percent over the entire period of the analysis, by 40 percent between 1999 and 2004, and by about 39 percent during the period 2009 and 2012. However, between 2005 and 2008 the world nominal Linseed oil price volatility exceeded its domestic counterpart by as much as 47 percent reflecting the commodity crisis that occurred during 2007/08. The real Linseed prices also followed the same trend except the difference in magnitude of volatility. A similar trend is also observed in the Rapeseed price volatility differences, except the difference during the period between 2005 and 2008 has been the smallest observed volatility difference as the world Rapeseed price volatility has approached the higher domestic volatility. Both nominal and real Rapeseed price volatility had been higher in domestic markets than the World market. That is, the rapeseed volatility difference was as high as 49 and 47 percent between 2009 and 2012, and the lowest difference observed between 2005 and 2008 with 1 percent and 16 percent, in the nominal and real rapeseed prices volatility, respectively.

The above unconditional price volatility comparison over different time periods between 1997 and 2012 shows that over the entire period the unconditional price volatilities of oilseed items is higher in the domestic market than the World market. However, when observed periodically, the unconditional price volatility tracks the World market situation. This is to say that during the commodity market crisis the World oilseeds price volatility exceeded the domestic one in the case of Linseed oil and approached and narrowed the difference with the domestic price volatility in the case of Rapeseed. This, in turn, reveals two characteristics of the domestic oilseeds market. The first is related to the weaker integration of the domestic oilseeds market to the world market, as it did not buy out the World oilseeds price volatilities, especially during the 2007/08 commodity market crisis. In this regard, we conducted a Johansen (1988) cointegration test and the results show that the domestic Linseed market is not cointegrated with the world Linseed oil market, whereas domestic and world Rapeseed markets appear cointegrated with one cointegrating vector. The second is ascribed to the decline in the ratio of export to domestic production. Between 2006 and 2008, oilseeds export and import declined following the financial crisis implying that the decline in imports, that was as high as 24 thousand metric tonnes in 2006, was covered by the increased domestic supply that would have been exported.

Therefore, we may conclude that the increased domestic consumption insulated the domestic market from the volatility that would have been permeated into the domestic market and rock the already higher domestic oilseeds price volatility. With regard to the conditional variance estimate provided by the GARCH(1,1) for both domestic and World market volatilities of Linseed and Rapeseed, we observe that in the domestic market there is no problem of volatility persistence where as volatility persistence appear 
as the characteristic of the World market. What the markets for the two oilseed items have in common is the problem of volatility clustering. Nonetheless, the magnitude of the influence of the news about past volatility on current volatility differs across crops and markets. The magnitude of the influence of the news about past volatility (innovations) is more than 8 times larger in domestic markets than the World market for Rapeseed, and it is three times as large as the domestic market for Linseed. The GARCH terms are significant in both domestic and World markets except for Rapeseed in the domestic market implying that the impact of past variance on current variance is not statistically significant for domestic Rapeseed prices, though the magnitude of the change in current volatility in response to past volatility is about $29 \%$.

\section{Conclusion}

Prices of agricultural commodities undergoing rapid adjustments were in the spotlight following the food crises in late 2007 and 2008, and again more recently in the summer and fall of 2010, raising concerns about increased price volatility. The increased price volatility will have implications on household decisions (production and consumption) and government revenues, especially in countries where export earnings are concentrated on a limited number of primary commodities and constitute the larger share of government revenue. As one of the most important export items, oilseeds have been vital in the Ethiopian economy. When compared with cereals, which have negligible contribution in foreign exchange earnings, the oilseeds are important contributors to the country's foreign exchange earnings and have a huge potential to diversify the primary commodity export profile of the country, and hence sources of government revenue.

In this study, we have investigated and compared price volatilities of oilseeds in the domestic market and in the world market. We compare the volatilities in both markets using two oilseeds-Linseed and Rapeseed. The unconditional price volatility comparison over different periods between 1999 and 2012 shows that price volatilities of oilseeds were higher in the domestic market than the world market over the entire period. However, when observed periodically, the unconditional price volatility tends to follow the world market situation. This is to say that during the commodity market crisis the world oilseeds price volatilities exceeded the domestic levels in the case of Linseed, whereas in the case of Rapeseed the world volatility levels approached and narrowed the difference with the domestic Rapeseed price volatility. This, in turn, reveals two characteristics of the domestic oilseeds market. Firstly, domestic oilseeds market appear weakly integrated to the world market, as it did not buy out the world oilseeds price volatilities, especially during the 2007/08 financial crisis. Secondly, the decline in the ratio of export to domestic production may have helped in insulating the price boom in the international market. Between 2006 and 2008, oilseeds export and import declined following the financial crisis implying that the decline in imports, that was as high as 24 thousand metric tonnes in 2006, was covered by the increased domestic supply that would have been exported. Therefore, we may conclude that the increased domestic consumption insulated the domestic market from the volatility that could have been permeating into the domestic market and further increase the already higher domestic oilseeds price volatility.

With regard to the conditional variance estimates provided by the GARCH $(1,1)$ for both domestic and World market volatilities of Linseed and Rapeseed, we observe that in the domestic market there is no problem of volatility persistence where as volatility persistence appear as the characteristic of the World market. However, volatility clustering appears common problem in the two markets. The higher domestic oilseeds price volatility may imply that the price risks are high in the domestic oilseeds market. This might be a concern for the enhancement of the oilseeds sector`s production and export performance. As extreme price volatility influences farmers' production decision, they may opt to other less risky, lowvalue and less profitable crop varieties. The implications of such retreat is that it may keep the farmers in the traditional farming and impede their transformation to the high value crops, and results in lower income hindering the poverty reduction efforts of the government. This is more important to consider today than was before, because measures undertaken to reduce poverty must bring sustainable change in the lives of the rural poor. For this, reason, agricultural policies that enable farmers cope with price risks and enhance their productivity are crucial. We note that measuring the impacts of oilseeds price volatilities on producing households, and government revenue levels will depict a better picture of the envisaged implications on household welfare and government revenue. 
Acknowledgment: The author wishes to express profound gratitude to the University of Trento for the financial support of the study during his PhD study. The author also would like to thank Professor Christopher Gilbert for his constructive comments from the inception to the end of the study.

\section{References}

Balcombe, K. (2010). The Nature and Determinants of Volatility in Agricultural Prices: An Empirical Study from 1962-2008, in Commodity Markets Review 2006-2010, FAO, Rome.

Befekadu, D. \& Tesfaye, R. (1990). The Marketing and Pricing of Agricultural Products in Ethiopia. In Seigfried P., Fantu C., Brune S., \& Eshetu C. (eds.), Ethiopian Rural Development Options. London: Zed Books.

Bollerslev, T. (1986). Generalized autoregressive conditional heteroskedasticity. Journal of Econometrics, 31(3), 307-27.

CSA. (2013). Agricultural Sample Survey: Report on Area and Production of Major Crops, Vol. I, No. 532, Addis Ababa

CSA. (2012). Agricultural Sample Survey: Report on Crop and Livestock Product Utilization, Vol. VII, No. 532, Addis Ababa

Dehn, J. C., Gilbert, L. \& Panos, V. (2005). Agricultural Commodity Price Volatility, in Managing Economic Volatility and Crisis: A Practitioner`s Guide, ed. Joshua A. and Brian Pinto. The World Bank, Cambridge University Press.

Engle, R. F. (1982). Autoregressive conditional heteroscedasticity with estimates of the variance of United Kingdom inflation. Econometrica, 50(4), 987-1007.

Engle, R. F. \& Bollerslev, T. (1986). Modelling the persistence of conditional variance. Econometric Reviews, 5(1), 1-50.

Johansen, S. (1988), Statistical analysis of cointegrating vectors. Journal of Economic Dynamics and Control, 12, 231-254.

OECDSTAT. (2013). OECD-FAO Agricultural Outlook2011-2020. Available at: http://stats.oecd.org/, data extracted on Feb 19, 2013.

Rashid, S., Chilot Y., Befekadu B. \& Solomon, L. (2010). Pulses Value Chain in Ethiopia: constraints ad opportunities for enhancing exports, International Food Policy research Institute Working Paper, July 2010.

Rashid, S., Meron A. \& Gezahegn A. (2009). Distortions to Agricultural Incentives in Ethiopia, in Distortions to Agricultural Incentives in Africa, Kym Anderson and William A. Masters (Eds): The World Bank, Washington D.C.

USAID (2010). Staple Foods Value Chain Analysis: Country Report, Competitiveness and Trade Expansion Program: April 2010

\section{Appendix A}

\section{Domestic Production, Area cultivated and yield, Oilseeds}

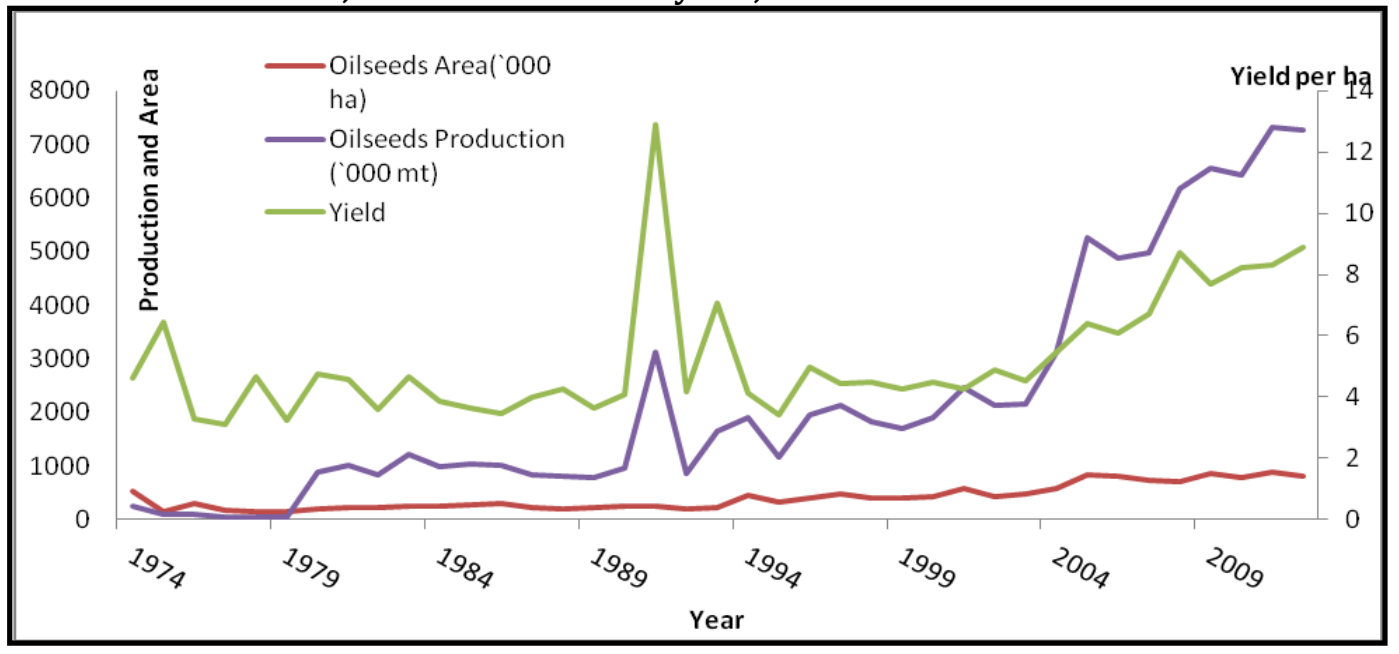




\section{Appendix B}

Unit Roots Test

Table 10: Unit roots test for domestic oilseeds (log of price returns)

\section{ADF Test Statistics}

\begin{tabular}{llll} 
Lags & Linseed & Niggerseed & Rapeseed \\
\hline 0 & $-12.93^{* *}$ & $-14.38^{* *}$ & $-11.48^{* *}$ \\
1 & $-7.935^{* *}$ & $-9.145^{* *}$ & $-7.752^{* *}$ \\
2 & $-6.526^{* *}$ & $-6.959^{* *}$ & $-5.722^{* *}$ \\
3 & $-5.976^{* *}$ & $-6.450^{* *}$ & $-5.860^{* *}$ \\
\hline ** indicates $1 \%$ significance level, ADF tests $(\mathrm{T}=162$, Constant; $5 \%=-2.881 \%=-3.47)$
\end{tabular}

Table 11: Unit root test for World Oilseeds Prices (log of price returns

\begin{tabular}{lllll}
\hline \multicolumn{5}{c}{ ADF Test Statistic } \\
Lag & Linseed Oil & Palm Oil & Soybean Oil & Rapeseed \\
\hline 0 & $-9.180^{* *}$ & $-8.726^{* *}$ & $-9.115^{* *}$ & $-9.836^{* *}$ \\
1 & $-7.018^{* *}$ & $-9.207^{* *}$ & $-7.733^{* *}$ & $-7.793^{* *}$ \\
2 & $-5.575^{* *}$ & $-6.351^{* *}$ & $-6.173^{* *}$ & $-5.812^{* *}$ \\
3 & $-5.184^{* *}$ & $-4.798^{* *}$ & $-4.751^{* *}$ & $-5.003^{* *}$ \\
\hline$* *$ & indicates $1 \%$ significance, ADF tests $(\mathrm{T}=163$, Constant; $5 \%=-2.881 \%=-3.47)$
\end{tabular}

\section{Appendix C}

1. Graph of Oilseeds Price Returns

Figure 12: World market Oilseeds price returns

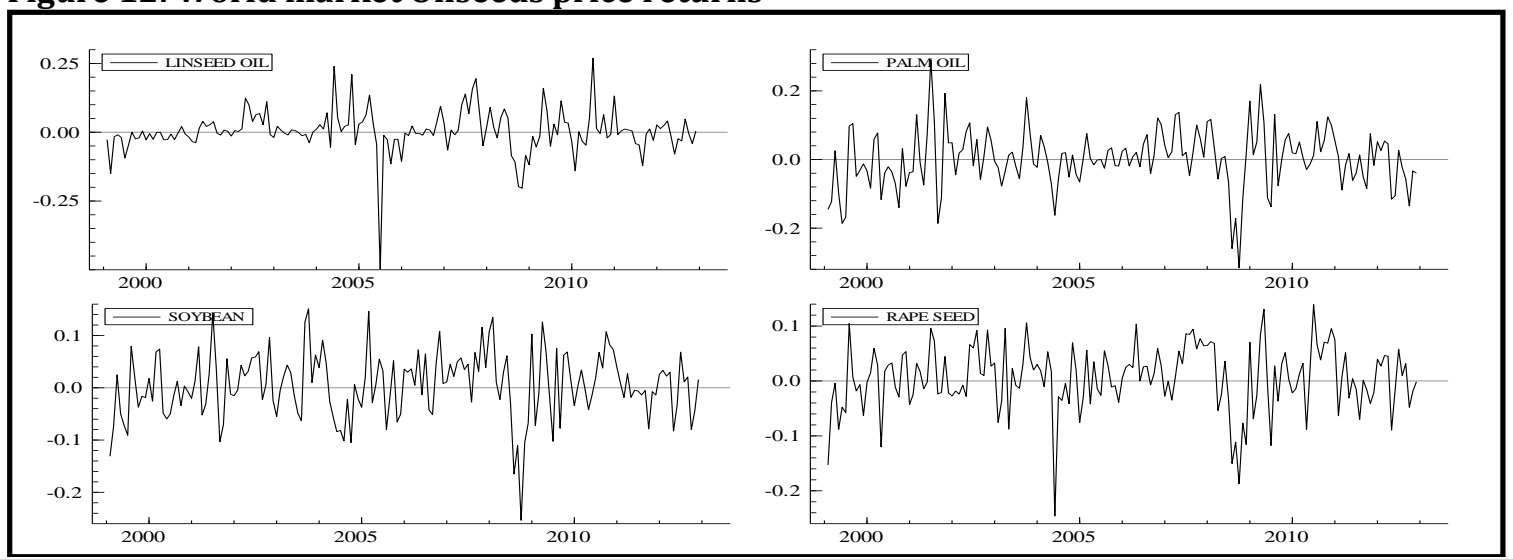

Figure 9: Conditional Variance of World Oilseeds Prices

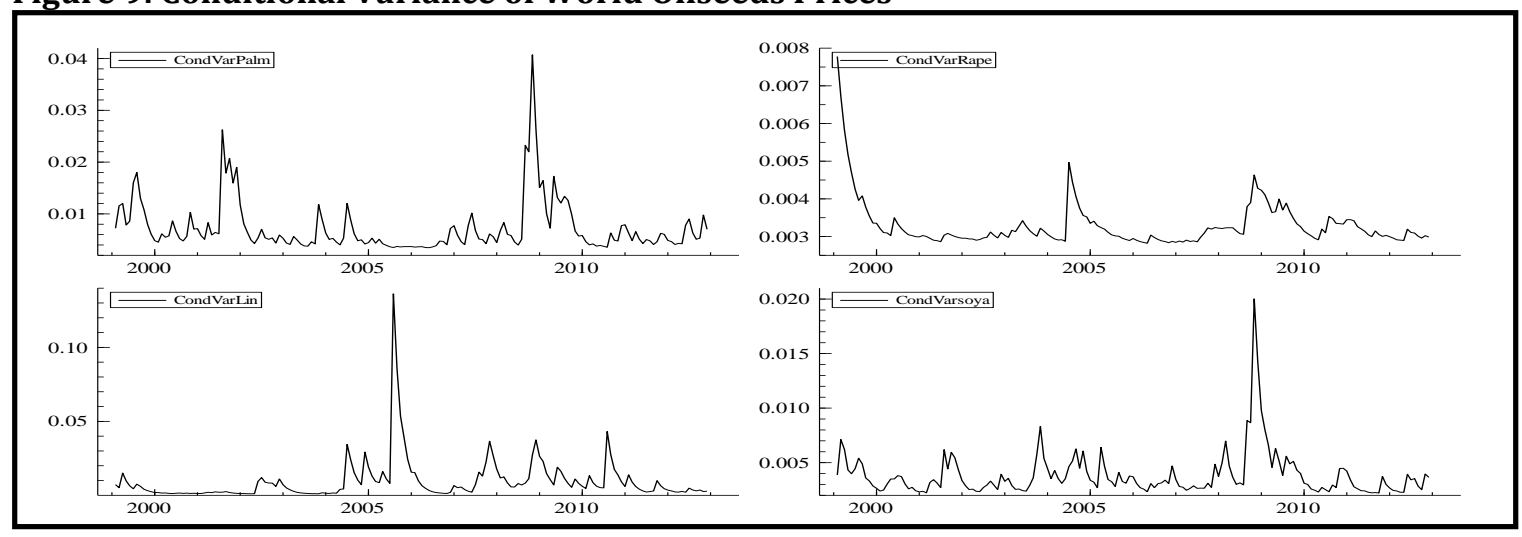




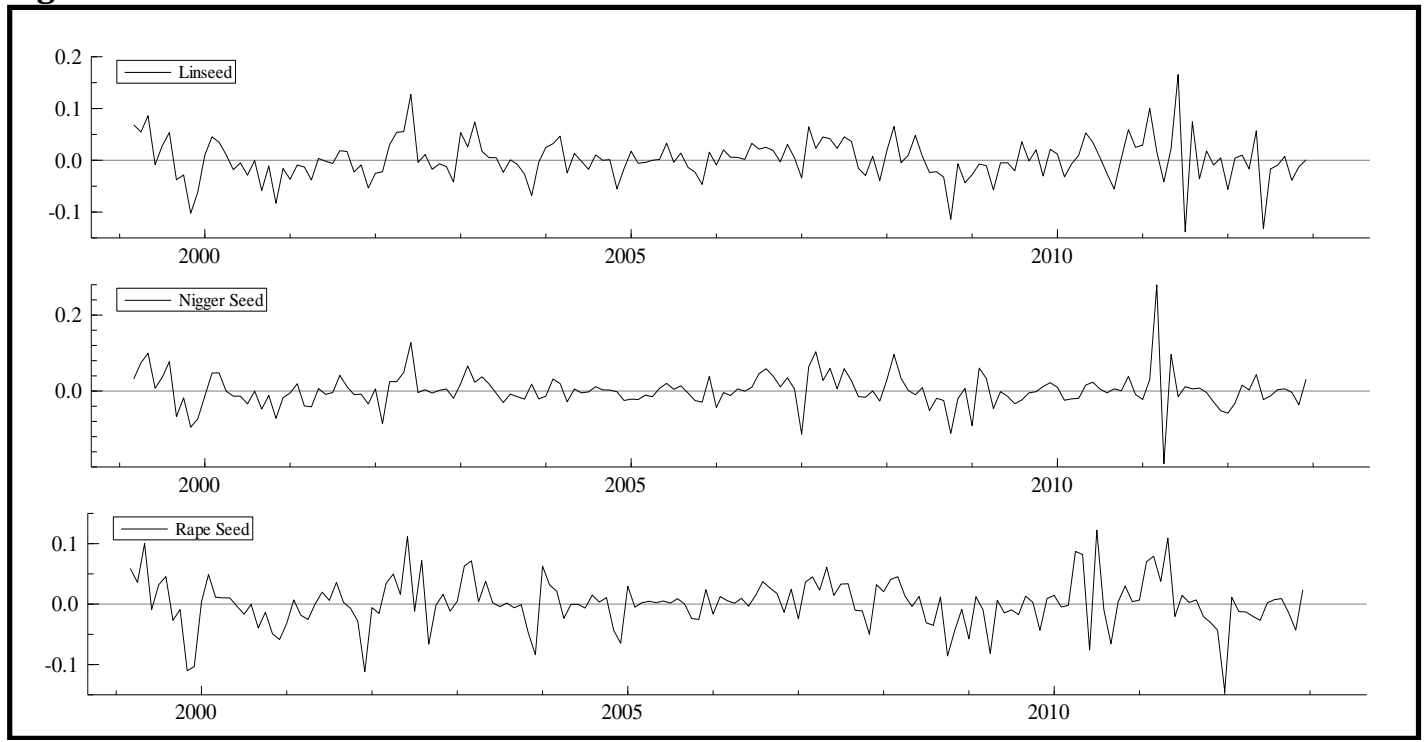

Figure 11: Conditional Variance of Domestic Oilseeds
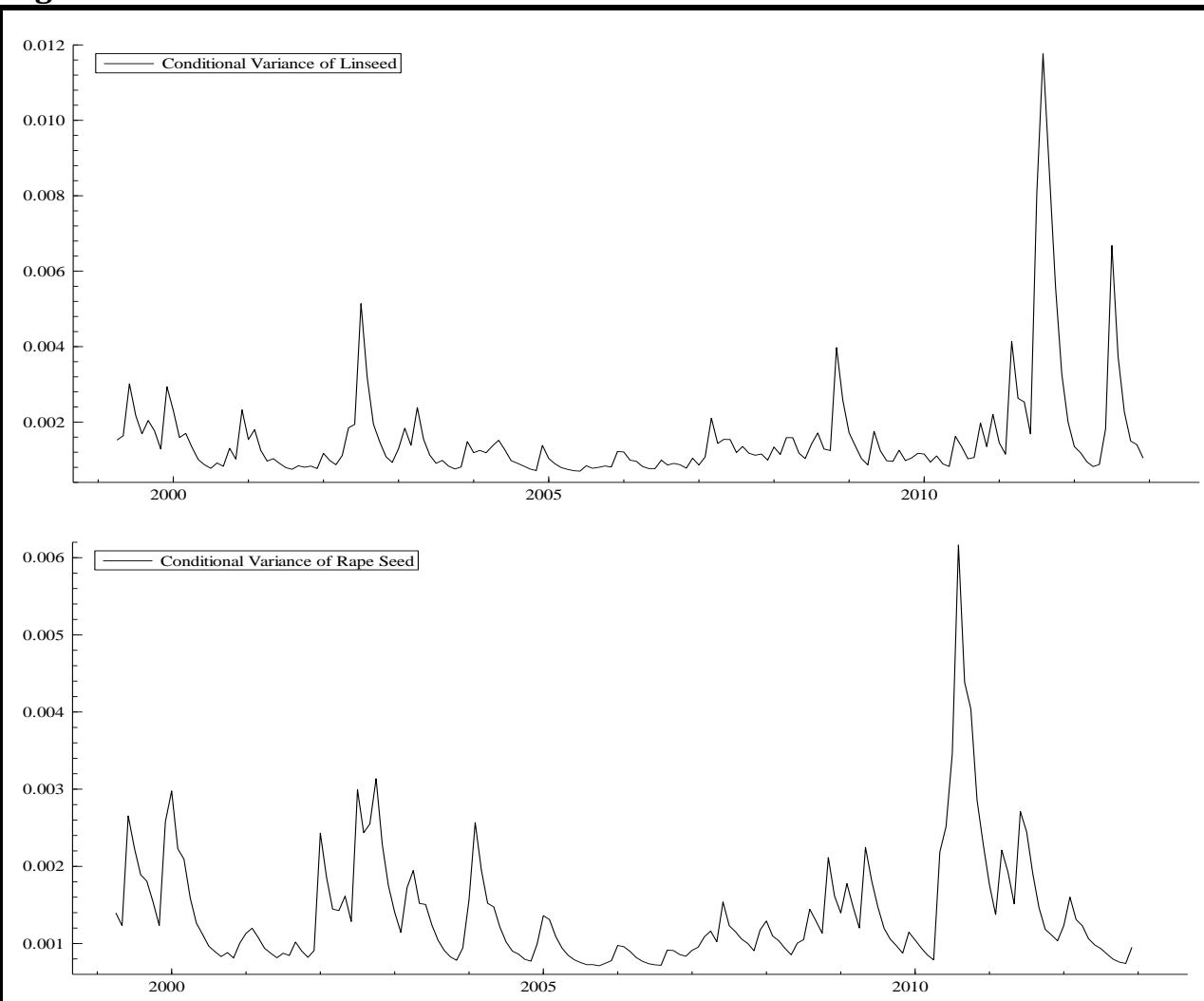